\title{
Early surgical revascularization after acute myocardial infarction
}

\author{
S Borovic ${ }^{1 *}$, P Dabic ${ }^{1}$, I Nesic ${ }^{1}$, A Milutinovic ${ }^{1}$, S Dzelebdzic ${ }^{2}$, B Djukanovic $^{1}$ \\ From 23rd World Congress of the World Society of Cardio-Thoracic Surgeons \\ Split, Croatia. 12-15 September 2013
}

\section{Background}

Treatment of myocardial infarction has undergone great evolution since introduction of percutaneous coronary intervention. The purpose was to assess the outcome of patients with myocardial infarction undergoing early surgical revascularization with coronary artery bypass grafting (CABG).

\section{Methods}

A total of 62 consecutive patients underwent CABG therapy within 14 days after the onset of myocardial infarction between September 2009 and January 2013 at our institution. Prospectively recorded preoperative, intraoperative, and postoperative data were retrospectively screened for in-hospital mortality and major adverse postoperative events (low cardiac output syndrome, prolonged mechanical ventilation, prolonged intensive care stay, hospital stay $>7$ days).

\section{Results}

Overall in-hospital mortality was $3.2 \%$. Low cardiac output syndrome was found in $27.4 \%$, prolonged mechanical ventilation in 9,7\%, prolonged intensive care stay in 48,4\% and hospital stay $>7$ days in $64,5 \%$. Age, female sex, EuroSCORE, extent of preoperative myocardial necrosis, low left ventricular ejection fraction and cardiogenic shock were the most potent predictors of major adverse postoperative events.

\section{Conclusions}

CABG within 14 days after the onset of myocardial infarction can be performed with acceptable risk by incorporating adequate management strategies. However, age, female sex, extent of preoperative necrosis,

\footnotetext{
* Correspondence: sborovic2001@yahoo.com

${ }^{1}$ Cardiac Surgery, Dedinje Cardiovascular Institute, Belgrade, Serbia

Full list of author information is available at the end of the article
}

preoperative cardiogenic shock and calculated high operative risk are major variables of morbidity results.

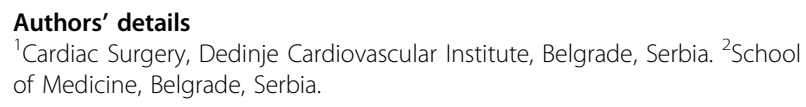

${ }^{1}$ Cardiac Surgery, Dedinje Cardiovascular Institute, Belgrade, Serbia. ${ }^{2}$ School of Medicine, Belgrade, Serbia.

Published: 11 September 2013

\section{doi:10.1186/1749-8090-8-S1-0173}

Cite this article as: Borovic et al:: Early surgical revascularization after acute myocardial infarction. Journal of Cardiothoracic Surgery 2013 8(Suppl 1):0173.
Submit your next manuscript to BioMed Central and take full advantage of:

- Convenient online submission

- Thorough peer review

- No space constraints or color figure charges

- Immediate publication on acceptance

- Inclusion in PubMed, CAS, Scopus and Google Scholar

- Research which is freely available for redistribution

Submit your manuscript at www.biomedcentral.com/submit

\section{() Biomed Central}

